\title{
DO RISK-BASED CAPITAL REQUIREMENTS ALLOCATE FINANCING AND CAUSE A "BIGGER" LOAN LOSS PROVISION FOR ISLAMIC BANKS?
}

\author{
Abdul Ghafar Ismail \\ Shahida Shahimi \\ University Kebangsaan Malaysia
}

\begin{abstract}
The purpose of the study is to examine the Islamic banks' response to the risk-based weighted capital requirements implemented in 1989. This paper will look at three possible effects; First, will the implementation of risk-based capital encourage substitution out assets in the 100 percent risk category such as deferred payment (debt contract) and, into assets in the less risky categories such as mudharabah and musharakah financing and government investment certificates? Second, will the implementation of risk-based capital $(R B C)$ discourage Islamic banks to utilize the equity financing upon subsidiary companies as the latter is deducted from the total capital base? Third, may the risk-based capital cause a "bigger" loan loss provision, as the concentration of financing is based on the debt contract? This study finds that Islamic banks could reduce financing portfolios in order to increase capital ratios. Second, the core capital ratio is enough to fulfill the $8 \%$ capital requirement indicating that Islamic banks do not rely on Tier-2 capital. Third, the higher percentage of debt financing may lead to the losses from debt financing that are entirely absorbed by banks and later, by depositors, resulting in lower return to depositors.
\end{abstract}

JEL Classification numbers: G15; G18; P51

Keywords: Islamic banking; bank capital; loan loss provision

\section{INTRODUCTION}

The studies on Islamic banks cover many areas. The areas, among others, cover: the role of Islamic banks in providing financing to economic growth (see, for example, Chapra (1992) and Siddiqi (1983)); the conceptual issues underlying the interestfree financing (see, Aggarwal and Yousef (2000), Ahmed (1989) and Karsen (1982)); the policy implications of a financial system without interest payments (see for example, Khan (1986), and Khan and Mirakhor (1987)); and the evaluation on Islamic banks performance (see, for example Bashir (2000)).

However, the design of Islamic financial system is not only confined to cover the above areas, but it also covers the regula- tory framework. ${ }^{1}$ The trust of surveillance regulatory framework is aimed to produce an effective and prudent Islamic banking system and hence; create a sound and stable financial system. Authors, like Lindgren, Garcia and Saal (1996), produce the evidence that the macroeconomic performance is related to banking system soundness. However the study that addresses the impact of regulatory framework on Islamic banking is very rare, except to our knowledge, in Errico and Farahbaksh (1998) and Malik (2000). They find that the majority regulators operate the same regulatory framework applies to both conventional and Islamic banks.

\footnotetext{
1 This framework encompasses two main fields, i.e. regulation and supervision
} 
One of this regulatory frameworks is risk-based capital $(\mathrm{RBC})$ requirements, that mandates the banks to hold capital in proportion to their total risk-weighted assets. It is expected that the implementation of riskbased capital would encourage substitution out assets in the 100 percent risk category such as deferred payment (debt contract) and, into assets in the less risky categories such as mudharabah and musharakah financing and government investment certificates. ${ }^{2}$ The implementation of RBC would also discourage Islamic banks to utilize the equity financing upon subsidiary companies as the latter is deducted from the total capital base. Thus, risk-based capital may cause a "bigger" loan loss provision, as the concentration of financing is based on the debt contract.

In addition, this paper is also aimed to provide additional evidence that regulatory framework becomes a constraint to the banks in providing equity financing and the rate of return on deposits is relatively lower than the interest rate where the banking system operates on the dual-basis.

The remainder of this paper is organized as follows. Section 2 reviews in brief on how both the risk-based weighted capital requirements and loan loss provision can be applied to Islamic banks. A method to assess the impact of capital requirements on banks' financing and loan loss provision will be explained in section 3. Sections 4 and 5 will discuss the results and conclusions, respectively.

\footnotetext{
2 The argument derived from Ramlah, et. al. (2001) shows that the equity financing is less risky because the risk is dispersed between the bank and the entrepreneur. Hence, the provision for losses is partly allocated to depositors.
}

\section{REGULATIONS ON RISK-BASED CAPITAL STANDARDS AND LOAN LOSS PROVISION \\ Risk-based Capital Regulation}

In 1986, U.S. federal banking agencies first proposed adoption of a risk-based capital measure that would take "explicit account of the differences in risks among a banking organization's assets and off-balance sheet items. The second major aims was to foster co-ordination among supervisory authorities from major industrial countries and in 1987 new risk-based capital rules were proposed based on a joint U.S/U.K agreement. The scope of the international effort was expanded further when the Basle Committee on Banking Regulations and Supervisory Practices modified and extended the U.S/U.K. agreement to set internationally consistent capital standards for 12 industrial countries.

In 1989, Bank Negara Malaysia adopted their risk-based capital guidelines based on the Basle Capital Accord. ${ }^{3}$ There are two components of risk-based capital the measurement of qualifying capital and the determination of risk-weighted assets. The measurement of the former is only half of the problem, indeed, perhaps the easier half. The latter component of risk-based capital is the measurement of asset risk, which is accomplished by assigning assets and off-balance sheet activities to categories based on perceived risk, weighting the categories, and summing the weighted categories to create risk-weighted assets.

Hence, the capital-asset relationship will ensure that they both move in tandem, so that any increase in risk which would not be adequately supported by capital would necessitate a concomitant increase in capital. Although, a risk-based capital approach has the advantage of reducing bank's incentive

\footnotetext{
3 Bank Negara Malaysia adopts the risk-based capital guidelines for locally incorporated banks and domestic banks, see Abd. Ghafar (1991)
} 
to engage in risky activities by requiring a higher level of capital backing, but allowing them to reduce their capital as they shift to safer activities. And also, the decline in the value of asset in the conventional banking system caused by two reasons; the changes in ownership and default in debt.

However, the adoption of risk-based capital standards for conventional banks led to several issues. ${ }^{4}$ First, some banks may maintain higher capital ratios than as required by regulators and/or an increase in ratios are achieved by increasing capital or reducing lending (see, for example Peek and Rosengren (1995)). Second, the fixed capital standards is successful in limiting risktaking by the banks relative to capital as intended, or whether banks are able to take actions to reduce their responsiveness either by shifting to riskier assets within the same weighting range, or through capital arbitrage.

In Islamic banking, the operation is characterized by two main elements; i.e, equity as one of the financing instruments, and risk-sharing approach. ${ }^{5}$ Both elements are expected to affect the denominator and numerator of risk-weighted capital ratio. Although the first attempt to study the adequacy of capital requirement for Islamic banks has been done by Mohammed (2000), but the study leave more gap for further examination especially on the issue of Islamic banking operation, where the deposit contracts allow both banks and depositors to share their profits or losses. Therefore, Ramlah et. al (2001) suggest for Tier-2, the components of general provisions for bad and doubtful debt should also be extended to include provisions for losses in Mudharabah fund. In general, the uses of deposits are invested in the bank's project which utilize the mudharabah principle. When the project

\footnotetext{
4 An intensive review of Basle Capital Accord and the impacts on bank behavior can be seen in BIS (1999). 5 See, Abd. Ghafar (1994)
}

fails, part of the losses is absorbed by the banks and therefore, a provision for these losses is required. It is suggested that this provision is calculated based on the degree of riskiness of the project or on the predetermined profit-sharing ratio. ${ }^{6}$

Total Risk-Weighted Assets (TRWA) should comprises a different weighted of risk assets. Although, Mohammed (2000) suggests that the capital adequacy norms assign each asset owned by a bank to one of four categories, which is parallel to conventional methods. Each risk category is assigned a "risk-weight," which is used to multiply the amounts in each risk category to determine the amount of capital required by the bank and summing the weighted categories to create TRWA. The first three weights is considered as equal as the conventional bank capital requirement.

However, the 100 percent component should comprise a small portion in the TRWA. It is supposed that the equity contract is more dominant in financing the capital structure of firms, therefore, the weighted component of this financing should be recognized and disclosed in the TRWA. The question arises on the appropriate of weighted (in percentage) assigned to a different contracts. Our basis in determining the percent weightage should be subjected to a predetermined profit-sharing ratio.

\section{Loan Loss Regulation}

The use of loan loss provision as a tool for managing capital (see, Moyer (1990), Collins et al. (1995), Beatty et al. (1995) and Ahmed et al. (1999)), earnings (see, Wall \& Koch (2000)) and as a signaling device (see, Beaver et al. (1989), Wahlen (1994) and Ahmed et al. (1999)) has always been of great interest to researchers. After the 1990 capital adequacy regulation

\footnotetext{
6 The components in Tier-1 and deduction remain the same as in conventional bank.
} 
revolution as provided under the Basle Capital Accord 1988, studies were done to identify the use of loan loss provision as a tool for capital management, earning management and as a signaling device.

Therefore, in the profit and loss account, bank is required to disclose loan loss provision. The immediate effect of an increase in loan loss provision is expected to reduce reported earnings. In addition, an increase in loan loss provision would also increase the loan loss reserve that is considered as part of the capital adequacy component. ${ }^{7}$ The provisioning of loans and their associated write-downs (offs) will cause a decline in capital adequacy measures. ${ }^{8}$ The extent of an increase in loan loss reserve on a bank's capital ratio would however depend on the percentage of loan loss reserve against risk-weighted asset of a bank.

Under the old capital regime, ${ }^{9}$ loan loss reserve count as part of primary capi$\operatorname{tal}^{10}$. Therefore an increase in loan loss reserve will increase the total capital ${ }^{11}$ of the bank. However, under the risk-based capital requirement regime ${ }^{12}$, loan loss reserve only counts up to $1.25 \%$ of the risk-weighted assets. The new regulation requires a bank to

7 Inclusion of loan loss reserve as part of the capital adequacy requirement as under the Basle Capital Accord provided a legitimate environment for banks to manage accounting accrual like loan loss provision. Via the levels of loan loss provision recognized in each accounting year, banks could choose the level of earnings and capital ratio they would like to maintain.

8 Measures of capital adequacy are generally calculated using the book value of assets and book value of equity.

9 Banks were required to hold primary capital and total capital exceeding $5.5 \%$ and $6 \%$ of total assets by FDIC and Federal Reserve System.

${ }^{10}$ Primary capital included book value of equity, loan loss reserves, perpetual preferred stock and mandatory convertible debt.

11 Total capital is the sum of primary capital, subordinated debt and limited life preferred stock.

12 Total capital divided into Tier-1 and Tier-2. maintain a minimum Tier-1 capital ${ }^{13}$ of $4 \%$ and total capital of $8 \%$ of risk weighted assets. In addition, Tier- 2 capital $^{14}$ cannot be more than Tier-1 capital. Therefore, since 1990, loan loss provision decreases Tier-1 capital whereas prior to 1989 , loan loss provision increased primary capital. ${ }^{15}$

In addition, bank managers have private information regarding the default risk inherent in the loan portfolio, their judgment is necessary in estimating the loan loss provision for each year. Bank managers can exercise discretion over the timing of provisions for certain loan losses (see, Wahlen (1994)); hence the accounting accruals are adjustable at year-end. By using this discretion, managers can choose the timing of recognition for loan losses and therefore uses loan loss provision as a tool to manage capital, earnings (income smoothing) and also as a signal to investors.

As in the case of Malaysia, Abd. Ghafar and Adelina (2002) find that the adoption on the Basle Capital Accord provided room for the management of loan loss provision. For the calculation of capital ratio, general provision was part of Tier-2 capital component. Specific provision was however excluded. This gives an avenue where banks could use their discretion over the amount of specific provision recognized in an accounting period.

\footnotetext{
13 Tier-1 Capital includes sum of book value of equity, qualifying non-cumulative perpetual preferred stock, and minority interest in equity accounts of subsidiaries less goodwill and other intangible assets.

${ }^{14}$ Tier-2 Capital is the sum of loan loss reserves (up to maximum of $1.25 \%$ of risk-weighted assets), perpetual preferred stock, hybrid capital instruments, perpetual debt, mandatory convertible debt securities, term subordinated debt and intermediated preferred stock.

15 Loan loss provision reduces the denominator of Tier1 capital ratio if loan loss reserve is greater than $1.25 \%$ of risk-weighted asset. Differentiation of Tier-1 capital ratio equation with respect to loan loss provision would yield

$\left\{-(1-\tau)^{*}(\right.$ denominator $)+($ numerator $\left.)\right\} /(\text { denominator })^{2}$
} 
Under the regulations issued by the Central Bank of Malaysia, each bank must set up provisions for loan losses at the end of each financial year. This provision consists of $1.5 \%$ of general provision, $50 \%$ of doubtful debts (financings), and $100 \%$ of bad debts (financings), in line with the four-fold classification of the status of loan. ${ }^{16}$

In Islamic banking, as mentioned by Afzal-ur-Rahman (1979), loan loss provision plays the same role as in conventional banks. However, Islamic banking's operation involves two tier partnerships, the first tier partnership representing the bank and depositors, i.e., the former uses the latter's savings; the second tier representing the bank and entrepreneur using profit-sharing and debt contracts. In this partnership, they share the profit from the investment according to the pre-determined percentage share that has been agreed. Liability for losses falls not only on the banks, but also on the depositors and entrepreneurs.

\section{RESEARCH DESIGN}

The focus of this section is an effort to produce an assessment of the impact of capital requirement and loan loss provision on Islamic bank's capital. Therefore, the design of this research will be concentrated on the effects of regulatory framework on: (a) banks' financing; and (b) loan loss provision/equity financing.

A new formula for risk-weighted capital ratio of Islamic bank can be written as:

\section{RWCR $=\frac{\text { Tier }-1+\text { Tier }-2-\text { Deduction }}{\text { TRWA }}$}

By adding the provision for losses in Mudharabah fund in the numerator, it increases the total capital base. At the same

\footnotetext{
${ }^{16}$ It is based on the second and third categories of provision, and can be categorized as also substandard and satisfactory.
}

time, if banks shift their portfolios into less risky assets, i.e., equity financing, they reduce the TRWA. Both measures are expected to increase the risk-weighted capital ratio ( $\mathrm{RWCR}$ ).

The following discussion will be focused on these two issues and the research will be designed as follows:

(a) The effects of capital requirements on banks' financing

The fact that the introduction of the Basle capital adequacy requirements is followed by an increase in bank capital ratios is insufficient evidence to conclude as the cause of the increase capital ratio. It is possible that banks may be subjected to regulatory pressure to increase their capital ratios over this period. Therefore, the questions that need to be addressed are; First, does the decline in debt financing and equity financing lead to increase their capital ratios? Second, by increasing the debt financing will the banks be able to transfer the losses to their depositors? To do so, banks may respond by changing their choice of financing. This task needs to be answered by using simple descriptive statistics.

(b) The effects of capital requirements on loan loss provision/equity provision

The level of provisions for loan losses can also affect the capital ratio of a bank. Periodic additions to loan loss reserves, by means of loan loss provisioning, are charged against current earnings. If a bank sets up loan loss provisions, its net income declines 17 and, as a result, retained earnings also decrease.

The level of retained earnings affects the capital ratio of a bank directly.

\footnotetext{
17 Reported net income will be less for the period in which the loan loss provision is taken, see Bosle (2001).
} 
Under risk-based capital regulation, loan loss reserves are not counted as Tier-1 capital, but as Tier-2 capital up to $1.5 \%$ of the bank's risk-weighted assets. Hence, from the perspective of meeting regulatory capital requirements, it is much more effective to allocate income to retained earnings, which are counted as Tier 1 capital than to allocate it to loan loss reserves. If a bank fails to set up loan loss provisions sufficient to cover the expected decline in real economic value of credits, the result is equivalent to an adjustment in its capital ratio.

However, several considerations should be taken into account in judging the extent of adjustment through loan loss provisions. According to the Central Bank guidelines, only general provisions could be recognized as supplementary capital. In the case of Malaysian commercial banks, loan loss provisions are included as supplementary capital up to $1.5 \%$ of risk-weighted assets. Loan loss provisions for doubtful and expected loss credits are provisions created against an identified deterioration in the value of particular assets although they are not allocated to these assets. To the extent that these provisions are not excluded from supplementary capital, and some banks could not set up 100 percent of expected loan losses as reserves, partial cosmetic adjustments can be made in the capital ratios through loan loss provisions.

\section{RESULTS}

The data are compiled from the annual report of Bank Islam Malaysia Berhad (BIMB) for the period of 1997 to 2001. Several variables will be used to analyze the above effects, i.e., the components of riskbased capital, risk-based capital ratio, riskweighted assets, and assets in different risk categories for all banks. The analysis is also designed to examine the following impacts: First, the increase in debt financing during the study periods. Second, the higher amount of debt financing that may increase the amount of loan loss provision. ${ }^{18}$ Third, some banks may sell part of their loans to Danaharta and then, buy bonds issued by Danaharta dan Danamodal. ${ }^{19}$ Fourth, a portion of loan losses could be absorbed by mudharabah deposits.

\section{Capital Requirements and Allocation of Financing}

Table 1 summarizes increases in the bank's capital ratio from 1997 to 2001 . The fact that the introduction of the capital requirements was followed by a decrease in bank capital ratios was normal. The risk-adjusted capital ratio of Islamic bank in the study period increased from $12.1 \%$ at the end of 1997 to $16.1 \%$ at the end of 2001 . This increase was due to the fact that core capital ratio increase from $10.3 \%$ to $14.8 \%$, while risk-weighted assets registered an increase from RM2,741.5 million to RM10,486.1 million. This suggests that Islamic banks were unable to limit the increase in their risk-weighted assets below that of total assets. As shown in Table 2 (Row 2), the ratio of total risk-weighted assets to total assets increased from $60.7 \%$ in 1997 to $101.5 \%$ in 2001.

\footnotetext{
18 The latter can affect the supplementary capital.

19 Both agencies perform the function as special purpose vehicle (SPV) agency as recommended by International Monetary Fund.
} 
Table 1: The Capital Adequacy Requirement for Islamic Bank (1997-2001)

\begin{tabular}{|l|c|c|c|c|c|}
\hline Year & $\mathbf{1 9 9 7}$ & $\mathbf{1 9 9 8}$ & $\mathbf{1 9 9 9}$ & $\mathbf{2 0 0 0}$ & $\mathbf{2 0 0 1}$ \\
\hline RWCR (\%) & 12.1 & 29.4 & 24.7 & 20.0 & 16.1 \\
\hline Core capital ratio (\%) & 10.3 & 28.4 & 23.8 & 19.0 & 14.8 \\
\hline Net financing over asset (\%) & 54.8 & 60.1 & 50.3 & 45.8 & 48.7 \\
\hline Total asset (RM million) & 4513.3 & 5018.6 & 6760.4 & 8492.3 & 10335.3 \\
\hline Total financing (net)(RM million) & 2470.1 & 3061.2 & 3403.5 & $3,886.9$ & 5033.1 \\
\hline Off-balance sheet (RM million) & 1833.2 & 2190.2 & 891.1 & 1062.8 & 1636.7 \\
\hline Total capital base (RM million) & 332.5 & 960.5 & 1015.4 & 1032.8 & 1086.3 \\
\hline TRWA (RM million) & 2741.5 & 3268.3 & 4044.3 & 9546.9 & 10486.1 \\
\hline $\begin{array}{l}\text { Tier-1 } \\
\text { (RM million) }\end{array}$ & 133.4 & 500.0 & 500.0 & 500.0 & 500.0 \\
$\begin{array}{l}\text { Paid up capital } \\
\text { Reserve }\end{array}$ & 148.9 & 427.9 & 462.7 & 478.5 & 497.3 \\
Total & 282.3 & 927.9 & 962.7 & 978.5 & 997.3 \\
\hline Tier-2 & & & & & \\
(RM million) Loan loss provision & 26.3 & 47.8 & 52.7 & 79.6 & 129.4 \\
Subordinate debt & 100.0 & - & - & - & - \\
\hline $\begin{array}{l}\text { Deduction } \\
\text { (RM million) }\end{array}$ & $(76.1)$ & $(15.2)$ & $(15.2)$ & $(25.2)$ & $(40.4)$ \\
\hline
\end{tabular}

Source: Bank Islam Malaysia Berhad, Financial Statement, 1997-2001.

Note:

a The data in second to fourth rows are in percentage, while the others are in RM million.

$\mathrm{b}$ This item is calculated by deducting loan loss provision from total financing.

The Islamic banks had no difficulties in raising Tier-1 capital, which began to increase in 1998 and the subsequent years. The most direct way for Islamic bank to raise its capital adequacy ratio is by increasing its capital. The total capital of Islamic bank grew by $50.4 \%$ on a yearly average basis from 1997 to 2001. And, the increase was more than that of risky assets that exhibited an increase of $43.4 \%$ during the same period. Among total capital, core capital (Tier-1) increased by $59.0 \%$ on a yearly average basis, while supplementary capital (Tier-2) rose by $15.4 \%$. The increase in both capitals was not offset by an increase of $11.7 \%$ of total deductions.
The composition ratio of riskweighted assets of Islamic bank changed much from the period of 1997 to 2001 (see, Table 2). The composition ratio of risky assets with 100 percent risk weight to total risky assets was $81.0 \%$ (end of 1997), $72.7 \%$ (2000) and 52.0\% (end of 2001). On the other hand, the composition ratio of lessrisky assets (50 percent) increased slightly. The ratio of risky assets with 10 percent and 20 percent riskweight to total risky assets increased from $0.0 \%$ to $1.3 \%$ and $5.1 \%$ to $33.5 \%$ during the same period, respectively. This suggests that Islamic bank reduce their risky assets with 100 percent risk weights and as a result, their capital adequacy ratio increases. 
Table 2: The Islamic Bank Compositions of Total Risk Weighted Assets

\begin{tabular}{|c|c|c|c|c|c|}
\hline Year & 1997 & $\mathbf{1 9 9 8}$ & $\mathbf{1 9 9 9}$ & $\mathbf{2 0 0 0}$ & $\mathbf{2 0 0 1}$ \\
\hline $\begin{array}{c}\text { TRWA/Total } \\
\text { assets (\%) }\end{array}$ & 60.7 & 65.1 & 55.5 & 60.7 & 101.5 \\
\hline $100(\%)$ & 2220.5 & 2539.4 & 2918.9 & 3751.4 & 5345.5 \\
& $(81.0)$ & $(77.7)$ & $(72.2)$ & $(72.7)$ & $(52.0)$ \\
\hline $50(\%)$ & 400.0 & 601.9 & 708.0 & 1422.2 & 1366.6 \\
& $(14.6)$ & $(18.4)$ & $(17.5)$ & $(13.8)$ & $(13.0)$ \\
\hline $20(\%)$ & 140.1 & 125.6 & 412.3 & 341.9 & 3513.8 \\
& $(5.1)$ & $(3.8)$ & $(10.2)$ & $(13.7)$ & $(33.5)$ \\
\hline $10(\%)$ & 0.9 & 1.5 & 5.1 & 15.1 & 140.6 \\
& $($ neg) & $($ neg) & $(0.1)$ & $(0.3)$ & $(1.3)$ \\
\hline $0(\%)$ & - & - & - & - & - \\
\hline TRWA & 2741.5 & 3268.4 & 4044.3 & 5161.8 & 10486.1 \\
(RM million) & & & & & \\
\hline
\end{tabular}

Source: Bank Islam Malaysia Berhad, Financial Statement, 1997-2001.

In the case of Malaysian Islamic bank, the ratio of core capital to total capital exceeds $91.8 \%$ compared to $84.9 \%$ of supplementary capital for the periods 1997 to 2001. Islamic banks have more room to increase their supplementary capital by issuing more subordinated debts or allocating more provisions. However, Islamic banks would not able to increase the supplementary capital during the study periods.

Banks can also increase their capital ratios by reducing their volume of financing. For example, they can sell off financing or convert financing to securities that have a lower risk-weight in calculating capital ratios. In the case of Islamic banks, total financing did not decline between 1997 and 2001. To support this finding, total financing growth increased by $5 \%$ from $26.0 \%$ in 1997 to $31.0 \%$ in 2001 . Assets with a 100 percent risk-weight increased by $28.1 \%$. Financing with a 50 percent risk-weight also rose by $41.7 \%$, and financing extended to other domestic financial institutions for which 20 percent risk-weight is applied increased drastically by $424.29 \%$ during the same period. Capital growth exceeded that of total financing, which rose only at $1.1 \%$.
In Malaysia, it is easy for Islamic banks to reduce their financing portfolios by selling off existing financing because the financing sale market is relatively well developed. Although, it is difficult for Islamic banks to reduce their loan levels by curbing credit to firms because they play an important role as financial intermediaries in the Malaysian Islamic financial market. But, these contradictory roles could explain why Islamic banks could reduce financing portfolios in order to increase capital ratios.

Banks can also effectively increase capital ratios by shifting to $20 \%$ riskweighted category. The share of this category to total risk-weighted increased from $5.1 \%$ in 1997 to $33.5 \%$ in 2001. This implies that Islamic banks converted some of their asset portfolios from financing to deposits with other financial institutions.

\section{Capital Requirements and Loan Loss Pro- vision}

In the case of loan loss provision in Islamic banks, the ratio of financing written off to total financing stood at $4.9 \%$ in 1997 , but increased to $13.1 \%$ in 2001 . This lead us to a question: how could this level of provisions for loan losses affect the capital ratio 
of Islamic banks? Periodic additions to loan loss reserves, by means of loan loss provisioning, are charged against current earnings. If Islamic banks set up loan loss provisions, its net income declines and, subsequently, retained earnings also decrease.

Table 3 (Row 2 and Row 3) presents the general provision over net financings and the loan loss reserve over total risk weighted assets. The figures show that the general provision is more than $1.5 \%$ of net financings. And, the Islamic banks also violate the loan loss reserves of more than $1.25 \%$ of total risk weighted assets. The tendency for loan loss reserve to be more than $1.25 \%$ of TRWA is higher, if Islamic banks record a general provision exceeding $1.5 \%$ of net financings.

Table 3: Total Deposits, Total Financing and their related statistics

\begin{tabular}{|c|c|c|c|c|c|}
\hline Year & 1997 & 1998 & 1999 & 2000 & 2001 \\
\hline Total deposit (RM million) & 3716.5 & 3493.6 & 5617.4 & 7458.6 & 9065.3 \\
\hline $\begin{array}{l}\text { Mudharabah Deposits } \\
\text { (RM million) }\end{array}$ & 2055.7 & 1313.5 & 3417.3 & 5413.6 & 6553.6 \\
\hline Provision for Losses & na & (36.9) & $(77.6)$ & $(63.2)$ & (280.3) \\
\hline Total financing (RM mil- & & 3211.5 & 3572.8 & 4161.1 & 5452.9 \\
\hline lion)Provision for losses & (50.4) & (150.3) & (169.3) & $(274.2)$ & (419.8) \\
\hline $\begin{array}{l}\text { Types of financing } \\
\text { (RM million)d }\end{array}$ & 38.9 & 31.5 & 39.5 & 29.0 & \\
\hline $\begin{array}{l}\text { Equity } \\
\text { financingc }\end{array}$ & (1.5) & $(0.9)$ & (1.1) & $(0.7)$ & \\
\hline Debt financing & $\begin{array}{r}2481.6 \\
(98.5)\end{array}$ & $\begin{array}{r}3179.9 \\
(91.1)\end{array}$ & $\begin{array}{r}3533.2 \\
(98.9)\end{array}$ & $\begin{array}{r}4131.8 \\
(99.3)\end{array}$ & \\
\hline $\begin{array}{l}\text { General provision over total } \\
\text { net financing }(\%)\end{array}$ & 2.0 & 4.9 & 4.4 & 7.1 & 8.3 \\
\hline $\begin{array}{l}\text { Loan loss reserve over TRWA } \\
(\%)\end{array}$ & 1.8 & 4.6 & 4.2 & 5.3 & 4.0 \\
\hline $\begin{array}{l}\text { Total financing (RM million) } \\
\text { Provision for losses }\end{array}$ & $\begin{array}{r}2520.5 \\
(50.4)\end{array}$ & $\begin{array}{l}3211.5 \\
(150.3)\end{array}$ & $\begin{array}{l}3572.8 \\
(169.3)\end{array}$ & $\begin{array}{l}4161.1 \\
(274.2)\end{array}$ & $\begin{array}{l}5452.9 \\
(419.8)\end{array}$ \\
\hline $\begin{array}{l}\text { Types of financing } \\
\text { (RM million) }{ }^{\mathbf{d}}\end{array}$ & 38.9 & 31.5 & 39.5 & 290 & \\
\hline $\begin{array}{l}\text { Equity } \\
\text { financingc }\end{array}$ & (1.5) & $(0.9)$ & (1.1) & $(0.7)$ & \\
\hline Debt financing & $\begin{array}{r}2481.6 \\
(98.5)\end{array}$ & $\begin{array}{r}3179.9 \\
(91.1)\end{array}$ & $\begin{array}{r}3533.2 \\
(98.9)\end{array}$ & $\begin{array}{r}4131.8 \\
(99.3)\end{array}$ & \\
\hline $\begin{array}{l}\text { General provision over total } \\
\text { net financing }(\%)\end{array}$ & 2.0 & 4.9 & 4.4 & 7.1 & 8.3 \\
\hline $\begin{array}{l}\text { Loan loss reserve over TRWA } \\
(\%)\end{array}$ & 1.8 & 4.6 & 4.2 & 5.3 & 4.0 \\
\hline
\end{tabular}

Source: Bank Islam Malaysia Berhad, Financial Statement, 1997-2001.

Note:

c refers to mudharabah and musharakah financings

$d$ data in parentheses are the percentage of debt or equity financing to total financing 
Then, we are able to relate this finding to the bank's core capital ratio and risk weighted capital ratio in Table 1 . When the loan loss reserve exceeding $1.25 \%$ of TRWA, Islamic bank has core ratio of more than $8 \%$ during the study periods. This means that bank's core capital ratio is enough to fulfil the $8 \%$ capital requirement. Its risk-weighted capital ratio ranges from $12.1 \%$ to $16.1 \%$, i.e., Islamic banks easily ended up with risk-weighted capital ratio well above the regulatory minimum of $8 \%$. The result also indicates that Islamic bank generally do not rely on Tier-2 capital to fulfil the capital requirement.

The operation of Islamic banks also allows the losses to be shared among the stakeholders, i.e., banks, depositors and entrepreneurs. Therefore, it could be suggested that Islamic banks can have a lower riskweighted capital ratio because the losses from mudharabah or musharakah financing are partly absorbed by the depositors, entrepreneurs and banks. The figure in Table 3 shows that the share of mudharabah deposits to total deposits is $55.3 \%$ in 1997 and increase to $72.3 \%$ in 2001 . These deposits are mainly channelled to debt financing. As at the end of 1997 and 2000, the share of debt financing to total financing is $1.5 \%$ and $0.7 \%$, respectively. Therefore, the losses from debt financing are entirely absorbed by banks and later, by depositors. The provision for mudharabah losses increased from $2.8 \%$ in 1998 to $4.3 \%$ in 2001 . This may bring in a lower return to depositors.

\section{CONCLUSION}

This paper reports results, using time series data of capital requirements on Islamic banks over the period 1997-2001. The results indicate that: First, Islamic banks could reduce financing portfolios in order to increase capital ratios. Second, the Islamic banks' core capital ratio is enough to fulfil the $8 \%$ capital requirement. The result indi- cates that Islamic banks do not rely on Tier2 capital to fulfil the capital requirement. Third, the higher percentage of debt financing may lead to the losses from debt financing that are entirely absorbed by banks and later, by depositors bringing in a lower return to depositors.

\section{REFERENCES}

Abd. Ghafar Ismail (1991) On the adequacy of bank capital regulations. Malaysian Management Review 26, 19-23

Abd. Ghafar Ismail and Adelina Tan Be Lay (2002) Bank loans portfolio composition and the disclosure of loan loss provision: an empirical evidence of Malaysian banks. Asian Review of Accounting (Forthcoming)

Abd. Ghafar Ismail (1994) Profit-sharing in a model of bank behaviour. Jurnal Ekonomi Malaysia 28, 59-71

Afzal-ur-Rahman (1979) Economic doctrines of Islam. Lahore: Islamic Publications Ltd.

Aggarwal, Rajesh K. and T. Yousef (2000) Islamic banks and investment financing. Journal of Money, Credit and Banking 32, 93-120

Ahmed, A.S., Takeda, C., Thomas S. (1999) Bank loan loss provisions: a reexamination of capital management, earnings management and signaling effects. Journal of Accounting and Economics 28: 125

Ahmed, S, (1989) Islamic banking and finance: a review essay. Journal of Monetary Economics 24, 157-167

Basel Committee on Banking Supervision (BIS). (1999). Sound practices for loan accounting and disclosures 
Bashir, A. (2000) Determinants of profitability and rate of return margins in Islamic banks: some evidence from the Middle East. Paper presented at the ERF's Seventh Annual Conference, Amman, October, 26-29

Beatty, A., Chamberlain, S.L., Magliolo, J. (1995) Managing financial reports of commercial banks: the influences of taxes, regulatory capital and earnings. Journal of Accounting Research 33(2): 231262

Beaver, W., Eger, C., Ryan, S., and Wolfson, M. (1989) Financial Reporting, supplemental disclosures, and bank share prices. Journal of Accounting Research 27 (Autumn) 157-178

Blose, L. E. (2001) Information asymmetry, capital adequacy, and market reaction to loan loss provision announcements in the banking industry. The Quarterly Review of Economics and Finance 41 239-258

Chapra, M. Umer (1992) Islam and the economic challenge. Leicester: The Islamic Foundation.

Collins, J., Shackelford, D., and Wahlen, J. (1995) Bank differences in the coordination of regulatory capital, earnings and taxes. Journal of Accounting Research 33(2): 263-291

Errico, L. and M. Farahbaksh (1998) Islamic banking: issues in prudential regulations and supervision. IMF Working Paper no. WP/98/30

Karsen, I. (1982) Islam and financial intermediation. IMF Staff Papers

Khan, M. (1986) Islamic interest free banking: a theoretical analysis. IMF Staff Papers

Khan, M. and A. Mirakhor (1987) Theoretical studies in Islamic banking and finance. Houstan: IRIS Books
Lindgren, C., G. Garcia, and M. Saal (1996) Bank Soundness and Macroeconomic Policy. Washington D.C.: IMF

Malik, N. (2000) Regulatory framework needed if Islamic banking to advance further. www.IslamiQ.com. Dec. 14

Mohammed, O. (2000) Capital adequacy norms for Islamic financial institutions. Research paper. http://islamicfinance.net/research/paper2.html

Moyer, S. 1990. Capital adequacy ratio regulations and accounting choices in commercial banks. Journal of Accounting and Economics 13: 123154

Peek, J. and E. Rosengren (1995) Bank regulation and the credit crunch. Journal of Banking and Finance 19, 679-692

Ramlah Karsan, Nafisah Mohammed, Nur Azura Sanusi and Abd. Ghafar Ismail (2001) Capital adequacy for Islamic banks. Paper presented at the National Workshop on Capacity Building Towards Excellence in Economic Research and Policy Formulation, Universiti Utara Malaysia, April 23-24

Siddiqi, Muhammad N. (1983) Issues in Islamic banking. Leicester: The Islamic Foundation

Wahlen, J. (1994) The nature of information in commercial bank loan loss disclosure. Accounting Review 69(3): 455478

Wall, L.D., Koch, T.W. (2000) Bank loan loss accounting: A review of theoretical and empirical evidence. Federal Reserve Bank of Atlanta Economic Review. Second Quarter 